\title{
THE EFFECT OF SALINITY TO ACTIVITY AND EFFECTIVITY PHOSPHATE SOLUBILIZING BACTERIA ON GROWTH AND PRODUCTION OF PADDY
}

\author{
Sri Widawati \\ Research Center for Biology, Indonesian Institute of Sciences \\ Jl.Raya jakarta-Bogor km 46 Cibinong Science Center \\ E-mail : widadomon@yahoo.com
}

\begin{abstract}
This study aimed to determine the extent of phosphate solubilizing bacteria resistant to salinity and still be able to provide $\mathrm{P}$ for paddy plant. Research using completely randomized design with fertilizer treatments: (A) Bakteri Aerobacter aerogenes + Azotobacter indicus (B) Bakteri Bacillus thuringiensis + B. megaterium + Pseudomonas fluorescens, (C) Bakteri Nocardia mesentrica + Spirillum lipoferum, (D) Mix bakteri Pseudomonas fluorescens, Bacillus thuringiensis, B. megaterium, Nocardia mesentrica, Aerobacter aerogenes, Spirillum lipoferum, dan Azotobacter indicus, and (E) control (whitout inoculant), and salinity ( $\mathrm{NaCl}$ ): (1) $0 \%$ (0 grams / $7 \mathrm{~kg}$ soil), (2) $0.1 \%$ (7 grams / $7 \mathrm{~kg}$ soil), (3) $0.2 \%$ (14 g / $7 \mathrm{~kg} \mathrm{soil})$, (4) $0.3 \%$ (21 $\mathrm{g} / 7 \mathrm{~kg}$ soil), and (5) $0,4 \%$ (28 g / $7 \mathrm{~kg}$ soil). Thirty and one hundred days after transplanting (DAT), and then measured plant height, number of tillers, number and dry weight of whole grain paddy. The results showed that $0,1 \%$ ( $7 \mathrm{gram} / 7 \mathrm{~kg}$ tanah) salinity is very good for the growth, activity and effectiveness of phosphate solubilizing bacteria and production of paddy, but $0.4 \%$ salinity $(28 \mathrm{gr} / 7 \mathrm{~kg}$ land) is still safe on the growth, activity and effectiveness of phosphate solubilizing bacteria (Pseudomonas fluorescens, Bacillus thuringiensis, B. megaterium, Nocardia mesentrica, Aerobacter aerogenes, spirillum lipoferum and Azotobacter indicus) as biofertilizer or growth promoting rhizobacteria on growth and production of paddy.
\end{abstract}

Key words: Salinity, Phosphate solubilizing bacteria, Paddy

\section{INTRODUCTION}

Salinity is the dissolved salt content which has units of milligrams per liter ( $\mathrm{mg} / \mathrm{L}$ ) or decisiemens per meter $(\mathrm{dS} / \mathrm{m})$, with salinity values around $30 \mathrm{dS} / \mathrm{m}$ for sea water and 0.3 $\mathrm{dS} / \mathrm{m}$ for ordinary water (Water, 2007). High salinity is the cause of death of bacteria and plants, especially paddy (Widawati, 2012). As an attempt for the survival of paddy plants, then had to isolate phosphate solubilizing bacteria from saline environments (coastal ecosystems). Bacteria are expected to help provide an element of $P$ for growth and production of paddy in the high saline levels, especially the breeding and the beginning vegetative growth. Phosphor element is the main element (essential) needed in the metabolic processes of plants and plants just absorb it in the orthophosphate ions $\left(\mathrm{H}_{2} \mathrm{PO}_{4^{-}}\right.$and $\left.\mathrm{HPO}_{4^{-}}\right)$ (Kustiyaningsih, 2003). Phosphate solubilizing bacteria is one of biofertilizer (growth promoting rhizobacteria), that can live in coastal tidal, offshore, coastal, marine and mangrove ecosystem (Seshadri et al., 2002). The bacteria produce are vitamins and phytohormones which can improve the growth of plant roots and increases nutrient uptake (Glick, 1995), and can produce the enzyme ACC deaminase (1-aminocyclopropane-1-carboxylate deaminase EC4.1.99.4) in the cytoplasm, especially Pseudomonas sp. strain ACP (Honma and Shimomura, 1978). The bacteria has been helping plants grow in saline environments (Husen, 2011). So, phosphate solubilizing bacteria it can be used to supply the soil organic matter (Husen et al., 2007) and stimulate plant growth. 


\section{MATERIALS AND METHODS}

Pseudomonas fluorescens, Bacillus thuringiensis, B. megaterium, Nocardia mesentrica, Aerobacter aerogenes, spirillum lipoferum and Azotobacter indicus are the pure isolates were isolated from the coastal areas. The bacteria have the ability to dissolve $P$ analyzed quantitatively and qualitatively, and survival of bacteria in solid and liquid media of pikovskaya that have different levels of salinity $(\mathrm{NaCl} 0 \% / 0 \mathrm{~g} ; 0.1 \% / 1 \mathrm{~g} / \mathrm{L}, 0.2 \mathrm{~g} / 2 \mathrm{~g} /$ $\mathrm{L}, 0.3 \% / 3 \mathrm{~g} / \mathrm{L}, 0.4 \% / 4 \mathrm{~g} / \mathrm{L}$ ). Then made of solid inoculant and inoculated into paddy plants. Planting paddy in the pot (50 pots) containing $7 \mathrm{~kg}$ of paddy soil / pot (soil $\mathrm{pH}=7$ ). Each pot planted 4 seed paddy, then given same of base fertilizer, and given the different inoculants and percentage of different salinity. Research using completely randomized design, repeated 3 times with fertilizer treatments: (A) Aerobacter aerogenes + Azotobacter indicus (B) Bacillus thuringiensis + B. megaterium + Pseudomonas fluorescens, (C) Nocardia mesentrica + Spirillum lipoferum, (D) Mix : Pseudomonas fluorescens, Bacillus thuringiensis, B. megaterium, Nocardia mesentrica, Aerobacter aerogenes, Spirillum lipoferum, dan Azotobacter indicus, and (E) control (whitout inoculant), and salinity ( $\mathrm{NaCl})$ : (1) $0 \%$ ( 0 grams $/ 7 \mathrm{~kg} \mathrm{soil),} \mathrm{(2)} 0.1 \%$ ( 7 grams $/ 7 \mathrm{~kg}$ soil), (3) $0.2 \%$ ( $14 \mathrm{~g} / 7 \mathrm{~kg}$ soil), (4) $0.3 \%$ (21 g / $7 \mathrm{~kg}$ soil), and (5) $0,4 \%$ ( $28 \mathrm{~g} / 7 \mathrm{~kg}$ soil). Thirty and one hundred days after transplanting (DAT), and then measured plant height, number of tillers, number and dry weight of whole grain paddy, available P and PME-ase soil before and after harvest, soil salinity and bacterial populations in the soil (pot) after harvest

\section{RESULTS AND DISCUSSION}

Phosphate solubilizing bacteria that have been tested in the study were able to survive (population mean $=10^{9}$ down to $10^{6}$ cells / g soil) in saline soil with $\mathrm{NaCl}$ content of $0 \%$ $0.4 \%$. As in the Seshadri's research, showed genus of Pseudomonas and Bacillus can survive in saline environments (Seshadri et al, 2002). The higher levels of salt given the growing media $(0.4 \%)$, apparently the lower impact of growth and production results. It is seen in Table 1, which is the average yield of plant height, fresh weight, panicle, number of trees of paddy, grain wet weight, dry weight and grain after harvest. The pots of A1, B1, C1, D1, and $\mathrm{E} 1$ with $0.1 \%$ salinity has an average yield of the highest harvest than plants growing in the pots with $0.2 \%$ saline (A2, B2, C2, D2, E2) , $0.3 \%$ (A3, B3, C3, D3, E3), $0.4 \%$ (A4, B4, C4, $\mathrm{D} 4, \mathrm{E} 4)$, and without salt (A0, B0; $\mathrm{C0}$; D0, and $\mathrm{E} 0)$. Bacteria in the inoculants (A, B, C, D, E) are still a good effect on crop yield of paddy in saline concentration of $4 \%$, when compared to plants that were not given inoculant but given saline (E1-E4) and plants not given salt and inoculant (E0). The best or highest influence is shown by the crop (plant height, number of tillers, number and dry weight of whole grain paddy) on the pot are A1, B1, C1, D1, and E1 code were given $0.1 \%$ saline. While the lowest result is shown by the control plants (without inoculant $=E 4)$. Average number of grains of paddy as the final product was still good, especially on pot group C (C1, C2, C3, C4), and D (D1, D2, D3, D4). 
Table 1. Average yield of plant height, fresh weight panicle, number of tillers, fresh weight of grains, and dry weight of grains

\begin{tabular}{|c|c|c|c|c|c|c|}
\hline $\begin{array}{l}\text { Inoculant } \\
\text { code }\end{array}$ & $\begin{array}{l}\text { Level of } \\
\mathrm{NaCl} \\
(\%)\end{array}$ & $\begin{array}{l}\text { Plant } \\
\text { height } \\
(\mathrm{cm})\end{array}$ & $\begin{array}{l}\text { Fresh weight } \\
\text { panicle } \\
\text { (gram) }\end{array}$ & $\begin{array}{l}\text { Number of } \\
\text { tillers per } \\
\text { pot }\end{array}$ & $\begin{array}{l}\text { Fresh weight } \\
\text { of grains } \\
\text { (gram) }\end{array}$ & $\begin{array}{l}\text { Dry weight } \\
\text { of } \\
\text { grains(gram) }\end{array}$ \\
\hline A0 & 0 & $90.5 \mathrm{~h}$ & $19.55 n$ & $13 \mathrm{~g}$ & $6.39 d$ & $3.58 b$ \\
\hline A1 & 0,1 & $97.5 \mathrm{i}$ & $26.86 p$ & $28 q$ & 26.860 & $12.96 \mathrm{ij}$ \\
\hline A2 & 0,2 & $88.5 \mathrm{fgh}$ & $17.8 \mathrm{~m}$ & $18 m$ & $19.57 n$ & $11.03 \mathrm{~h}$ \\
\hline A3 & 0,3 & $84 \mathrm{cdef}$ & $13.63 i$ & $15 i j$ & $17.79 m$ & 10.03gh \\
\hline A4 & 0,4 & $83.5 \mathrm{cdef}$ & $6.39 d$ & $9 d$ & $13.63 j$ & $7.14 \mathrm{f}$ \\
\hline B0 & 0 & 87.5efgh & $4.81 \mathrm{~b}$ & $11.5 \mathrm{e}$ & $4.81 \mathrm{~b}$ & $2.44 a$ \\
\hline B1 & 0,1 & $91.5 \mathrm{~h}$ & $34.95 \mathrm{~s}$ & $20.5 n$ & $30.45 q$ & $16.84 \mathrm{k}$ \\
\hline B2 & 0,2 & 85defg & $14.23 j$ & 14.5hi & $14.23 \mathrm{k}$ & $9.93 \mathrm{gh}$ \\
\hline B3 & 0,3 & $82.5 \mathrm{cde}$ & $10.24 h$ & $14 \mathrm{~h}$ & $11.64 \mathrm{i}$ & $5.57 \mathrm{e}$ \\
\hline B4 & 0,4 & $81 \mathrm{~cd}$ & $9.98 \mathrm{~h}$ & $12.5 f$ & $10.23 \mathrm{~h}$ & $4.81 \mathrm{~d}$ \\
\hline $\mathrm{CO}$ & 0 & 87.5efgh & $6.64 d$ & $7 \mathrm{c}$ & $9.98 \mathrm{~g}$ & $3.87 \mathrm{bc}$ \\
\hline C1 & 0,1 & $91.5 \mathrm{~h}$ & $36.77 \mathrm{u}$ & 220 & $36.77 \mathrm{t}$ & $21.28 \mathrm{~m}$ \\
\hline C2 & 0,2 & 87 efgh & $30.88 q$ & $15.5 \mathrm{jk}$ & $30.87 q$ & $21.02 \mathrm{~m}$ \\
\hline C3 & 0,3 & $82 \mathrm{~cd}$ & $33.37 r$ & $17 \mid$ & $33.3 r$ & $18.15 I$ \\
\hline C4 & 0,4 & $79.5 b c$ & $15.42 \mathrm{k}$ & $16 \mathrm{k}$ & 15.42 & $7.49 \mathrm{f}$ \\
\hline DO & 0 & $90.5 \mathrm{~h}$ & $5.55 \mathrm{~s}$ & $6 b$ & $5.55 \mathrm{c}$ & $2.76 a$ \\
\hline D1 & 0,1 & $89.5 \mathrm{gh}$ & $35.61 \mathrm{t}$ & $28.5 q$ & $35.61 \mathrm{~s}$ & $18.96 \mid$ \\
\hline D2 & 0,2 & 87.5efgh & $31.11 q$ & $26.5 p$ & $28.11 p$ & $13.53 \mathrm{j}$ \\
\hline D3 & 0,3 & $84 \mathrm{cdefg}$ & 25.30 & 220 & $25.3 n$ & $12.43 \mathrm{i}$ \\
\hline D4 & 0,4 & $74.5 b$ & $17.77 \mathrm{~m}$ & $18 m$ & $17.77 \mathrm{~m}$ & $11.59 \mathrm{~h}$ \\
\hline E0 & 0 & $82 \mathrm{~cd}$ & $3.91 \mathrm{a}$ & $5 a$ & $4.16 a$ & $2.4 a$ \\
\hline E1 & 0,1 & $89.5 \mathrm{gh}$ & $15.97 \mid$ & $20.5 n$ & $15.97 \mid$ & $9.66 \mathrm{~g}$ \\
\hline E2 & 0,2 & $80.5 \mathrm{~cd}$ & $9.33 \mathrm{~g}$ & $11.5 \mathrm{e}$ & $9.33 \mathrm{~g}$ & $4 \mathrm{bc}$ \\
\hline E3 & 0,3 & $80.5 \mathrm{~cd}$ & $8.69 f$ & $12.5 f$ & $8.69 f$ & $3.92 \mathrm{bc}$ \\
\hline E4 & 0,4 & $64.5 a$ & $7.62 \mathrm{e}$ & $7 \mathrm{c}$ & $7.03 e$ & $4.34 \mathrm{~cd}$ \\
\hline
\end{tabular}

Note: The number followed by the same letter in the same column are not significantly different by DMRT at $5 \%$ level.

This is all due to the survival of bacteria and bacterial activity and effectiveness in generating enzyme PME-ase, so as to provide $\mathrm{P}$ available that can be absorbed by the roots of plants in saline soil. This showed that the salt levels of $0 \%$ to $0.4 \%$ are still safe for bacterial life activities that effectiveness to produce the enzyme of phosphatase, so that P elements will always be freely available to the paddy crop. This is shown by the analysis of available $P$ in the soil and soil PME-ase during flowering and after harvest, the result is good (data not listed). As stated by Kholer et al (2009) and Husen (2011) in his research, that there is an imbalance of nutrients and increased uptake of $\mathrm{Na}^{+}$and decreased uptake of $\mathrm{K}^{+}$and $\mathrm{Ca}_{2}{ }^{+}$in plants, thereby disrupting the growth during the nursery and early vegetative growth impact on the results. So in general which gripped salinity plant hormone ethylene will menghasilkan in high concentrations due to accumulation of the compound ACC / ethylene precursor hormone (Husen, 2011). The results of this study can be concluded, that salt content of $0.1 \%$ is very good for growth, activity and effectiveness of phosphate solubilizing bacteria contained in fertilizer $A, B, C$, and $D$ on paddy production, but the salt content $0.4 \%$ is still safe for the growth, activity and effectiveness of bacteria the solvent phosphate as biofertilizer or growth promoting rhizobacteria. 


\section{ACKNOWLEDGMENT}

Authors would like to thank to the DIPA PN 5 project (coordinator: YB. Subowo MSc.) For their support in the implementation of research funding.

\section{REFERENCES}

Glick, B.R. 1995. The enhancement of plant growth by free-living bacteria. Can. J. Microbiol. Vol. 4: 109-117.

Honma, M., and T. Shimomura. 1978. Metabolism of 1-aminocyclopropane-1-carboxylic acid. Agric Biol Chem. Vol. 42 : 1825-1831.

Husen, E., R.M.D. Simanungkalit, Saraswati and Irawan. 2007. Characterization and quality assessment of Indonesian commercial biofertilizers. Ind. of Agr. Sci., Vol. 8 : 31-38

Husen, E. 2011. Ameliorasei cekaman salinitas pada padi sawah dengan bakteri penghasil ACC Deaminase. Laporan akhir program insentif riset terapan. Balai penelitian tanah. Balai besar litbang sumber daya lahan pertanian badan penelittian dan pengembangan pertanian kementrian.

Kohler, J., F. Caravaca, and A. Roldan. 2010. An AM fungus and PGPR intensify the adverse effects os salinity on the stability of rhizosphere soil aggregates of Luctuca sativa. Soil Biol. \& Biochem., Vol. 42: 429-434.

Kustiyaningsih. 2003. Pengaruh Sumber Karbon terhadap Aktivitas Bakteri Pelarut Fosfatdari Isolat Tanah Bukit Bangkirai, Kalimantan Timur. Skripsi. IPB. Bogor.

Pervaiz, Z., M. Afzal, Y.A. Xiaoe, and L. Ancheng. 2002. Selection criteria for salt-tolerance in wheat cultivars at seedling stage. Asian J. Plant Sci. Vol. 1: 85-87.

Water, S.A. 2007. Technical Guideline, General technical information for geotechnical design - Part K - Geotechnical SI Units System. South Australian Water Corporation.

Widawati, S. 2012. The Use Of Plant Growth Promoting Rizobacteria (Pseudomonas Fluorescens and Serratia Marcescens) for Paddy Growth in High Salinity Ecosystem. Seminar Nasional Biodiversitas IV, 15 September 2012. Universitas Erlangga, Surabaya. 